\title{
Tren Pemilihan Metode Kontrasepsi di Masyarakat di Beberapa Negara Dunia: Tinjauan
}

\author{
Trends in the Selection of Contraception Methods in Communities in \\ Several World Countries: A Review
}

\author{
Diena Karfiena Rahma Danti ${ }^{1}$, Rano Kurnia Sinuraya ${ }^{2,3}$ \\ ${ }^{1)}$ Program Studi Profesi Apoteker Universitas Padjadjaran, Jalan Raya Bandung-Sumedang KM. 21, Jatinangor, \\ Sumedang, Jawa Barat 45363, Indonesia \\ ${ }^{2)}$ Departemen Farmakologi dan Farmasi Klinik Universitas Padjadjaran, Jalan Raya Bandung-Sumedang KM. 21, \\ Jatinangor, Sumedang, Jawa Barat 45363, Indonesia \\ ${ }^{3)}$ Pusat Unggulan Iptek Perguruan Tinggi Inovasi Pelayanan Kefarmasian (PUI-PT IPK) Universitas Padjadjaran, \\ Jalan Raya Bandung-Sumedang KM. 21, Jatinangor, Sumedang, Jawa Barat 45363, Indonesia \\ Korespondensi: diena16001@unpad.mail.com
}

Submitted: 05 Juni 2020, Revised: 03 Agustus 2020, Accepted: 26 Agustus 2020

https://doi.org/10.22435/jpppk.v4i2.3182

\begin{abstract}
Abstrak
Saat ini kontrasepsi seakan menjadi kebutuhan primer. Layaknya Indonesia, negara lain menggunakan kontrasepsi guna menstabilkan pertumbuhan penduduk. Perkembangan keilmuan tentu berdampak langsung terhadap perkembangan metode kontrasepsi. Tinjauan artikel ini bertujuan untuk mengetahui tren dan faktor umum yang memengaruhi penggunaan kontrasepsi dalam lima tahun terakhir. Jurnal yang digunakan didapat dari laman situs Pubmed dan ScienceDirect dengan kata kunci "effectiveness of contraception"; "Trend of Contraception" dan "Cost Effectivenesss Analysis of Contraception". Kriteria jurnal terdiri dari kriteria inklusi dan kriteria eksklusi. Kriteria inklusi adalah jurnal berbahasa inggris yang dipublikasi lima tahun terakhir. Sementara kriteria eksklusi adalah jurnal riview dan jurnal yang membahas penggunaan kontrasepsi di suatu negara; populasi dengan penyakit tertentu. Sebanyak 18 jurnal dari 14 negara yang lolos ulasan dengan metode PICO. Mayoritas negara di dunia percaya bahwa long acting reversible contraceptive (LARC) merupakan metode kontrasepsi paling efektif. Tujuh dari empat belas negara menjadikan short acting reversible contraceptive (SARC) sebagai metode paling banyak digunakan. Faktor umum yang memengaruhi pemilihan kontrasepsi diantaranya tempat tinggal, agama, usia, aktivitas seksual, jumlah anak, dan tingkat pendidikan. Tren pemilihan metode kontrasepsi di dunia masih condong kepada SARC walaupun sudah banyak penelitian yang menyatakan LARC jauh lebih efektif dan cost-effective.
\end{abstract}

Kata kunci: Kontrasepsi, LARC, Faktor sosial

\begin{abstract}
Currently, contraception seems to be a primary need. Like Indonesia, other countries use contraception to stabilize population growth. Advances in science have an impact on the development of contraceptive methods. This review article aims to examine general trends and factors affecting contraceptive use in the past five years. The journals used were obtained from the Pubmed and ScienceDirect web pages with the keyword "effectiveness of contraception"; "Trend of Contraception" and "Cost-Effectiveness Analysis of Contraception". Journal criteria consist of inclusion criteria and exclusion criteria. The inclusion criterion is an English language journal published in the last five years. Exclusion criteria were review journals; study population with diseases. A total of 18 journals from 14 countries passed the review using the PICO method. The majority of countries in the world believe that long-acting reversible contraceptive ( $L A R C)$ is the most effective contraceptive method. Seven of the fourteen countries have made short-acting reversible contraceptive (SARC) the most widely used
\end{abstract}


method. General factors that influence the choice of contraception include a place of residence, religion, age, sexual activity, number of children, and level of education. The trend in choosing contraceptive methods in the world is still leaning towards SARC even though there have been many studies that have claimed that LARC is more effective and cost-effective.

\section{Keywords: Contraception, LARC, Social factors}

\section{Pendahuluan}

Tercatat populasi dunia pada tahun 1960 sekitar tiga miliar jiwa. Lima puluh tahun kemudian, populasi dunia meningkat lebih dari dua kali lipat. Saat ini populasi dunia mencapai 7,7 miliar dan diprediksi akan terus meningkat hingga 8,9 miliar pada tahun 2050. Penekanan tingkat pertumbuhan penduduk dimulai pada tahun 1975 dan terus dijaga hingga saat ini. ${ }^{1-3}$. Penekanan tingkat pertumbuhan penduduk terus dilakukan untuk mengontrol jumlah penduduk dan mencegah terjadinya ledakan penduduk dunia. Peningkatan populasi manusia yang tidak terkontrol dapat menimbulkan dampak negatif di beberapa aspek seperti aspek sosial, ekonomi, dan lingkungan. Meskipun korelasi antara pertumbuhan penduduk dan ekonomi masih menjadi kontroversi namun banyak ahli berpendapat pertumbuhan penduduk yang tinggi dapat memperlambat pertumbuhan ekonomi negara. Lambatnya pertumbuhan ekonomi suatu negara dapat memengaruhi keadaan sosial masyarakatnya. Pertumbuhan ekonomi yang lambat menyebabkan tingkat kemiskinan dan kelaparan meningkat, keadaan ini cenderung memicu tindakan kriminalitas dari masyarakat di suatu negara. ${ }^{4,5}$ Selain itu, pertumbuhan penduduk atau peningkatan populasi sejalan dengan meningkatnya eksploitasi sumber daya alam guna memenuhi kebutuhan hidup dasar manusia seperti makanan dan bahan bakar. Terjadi banyak kepunahan sumber daya tak terbarukan karena penggunaan bahan bakar tak terkendali. Aspek lingkungan yang sangat dipengaruhi oleh peningkatan populasi adalah pemanasan global. Pemanasan global terjadi karena semakin banyak penebangan hutan. Alasan umum dilakukan penebangan hutan karena peningkatan kebutuhan lahan guna tempat tinggal dan penggunaan kayu guna bahan bakar industri. Akibat dari penebangan hutan yang berlebihan terjadi pengurangan jumlah pohon yang mampu mengurangi polusi udara. Meningkatanya polusi udara tentu akan membawa dampak negatif bagi kesehatan manusia diantaranya penyakit paru kronis, penyakit kardiovaskular dan kanker. ${ }^{5-7}$

Bagi sebagian besar negara, pengendalian jumlah penduduk dilakukan dengan program kelurga berencana. Program keluarga berencana ditujukan untuk mengatur kehamilan masyarakat. Pencegahan kehamilan dilakukan dengan kontrasepsi. Kontrasepsi didefinisikan sebagai obat, alat atau cara yang dapat mencegah terjadinya pembuahan sel telur oleh sperma. ${ }^{8,9}$ Kontrasepsi seakan menjadi kebutuhan primer bagi masyarakat. Lebih dari 992 juta jiwa wanita usia produktif (1949 tahun) menggunakan kontrasepsi. Bukan hanya sekedar pencegahan kehamilan, banyak manfaat yang didapatkan melalui pengunaan kontrasepsi. Dengan pengurangan kehamilan akan menurunkan angka kematian ibu akibat kehamilan. Delapan puluh juta kehamilan tak diinginkan terjadi tiap tahunnya dan 42 juta di antaranya melakukan aborsi yang diinduksi. Rata-rata maternal mortality ratio dunia tahun 2000-2017 sebesar 38\%. Maternal mortality ratio diartikan sebagai jumlah kematian ibu per 100.000 kelahiran hidup. Diperkirakan sekitar 600.000 wanita meninggal tiap tahunnya akibat kehamilan. Selain pencegahan kehamilan, penggunaan kontrasepsi meningkatkan kesehatan ibu sehingga dapat memaksimalkan peran wanita dalam bermasyarakat. Kontrasepsi juga dapat meningkatkan tumbuh kembang anak dan kualitas keluarga sehat. ${ }^{4,10,11}$

Terdapat berbagai macam sistem pengelompokkan metode kontrasepsi, namun secara garis besar kontrasepsi dibagi menjadi 2 kelompok, kontrasepsi tradisional dan kontrasepsi modern. Kontrasepsi tradisional atau non-modern seperti periodik, coitus interruptus, metode berbasis kesuburan, dan metode amenorea laktasional. Sementara yang tergolong kontrasepsi modern diantaranya kondom pria dan wanita, kontrasepsi oral, injeksi, transdermal, cincin vagina, dan implan, intrauterine device (IUD). ${ }^{12,13}$ Kontrasepsi modern terbagi menjadi kontrasepsi 3 kelompok, 
yakni metode permanen, Long Acting Reversible Contraception (LARC), dan Short Acting Reversible Contraception (SARC). Metode permanen merupakan sterilisasi melalui proses pembedahan, yang tergolong dalam kelompok ini adalah tubektomi dan vasektomi. Tubektomi merupakan sterilisasi yang dilakukan pada wanita, sedangkan vasektomi merupakan sterilisasi yang dilakukan pada pria. ${ }^{14-16}$ Vasektomi merupakan proses sterilisasi pada pria dengan cara melakukan okulasi tabung pembawa sperma dari testis menuju penis (vas deferens), sehingga air mani pria tidak mengandung sperma. Tubektomi merupakan proses sterilisasi pada wanita dengan melakukan pemotongan pada sel indung telur atau tuba fallopi. ${ }^{17,18}$ LARC adalah metode kontrasepsi yang mampu mencegah pembuahan minimal 2 tahun. LARC tidak perlu digunakan setiap hari atau setiap bersenggama. Contoh LARC adalah IUD dan implan. Sementara SARC merupakan metode kontrasepsi kerja pendek yang harus digunakan setiap hari atau setiap bersenggama. Contoh dari SARC adalah injeksi (dilakukan tiap satu hingga tiga bulan), oral pil (digunakan setiap hari), dan kondom (digunakan setiap senggama). ${ }^{19,20}$

Banyaknya penemuan alat kontrasepsi tentu akan memberikan banyak pilihan bagi pasien yang ingin atau sedang menggunakan kontrasepsi. Dibutuhkan informasi tambahan agar pasien dapat memilih metode kontrasepsi yang tepat, metode kontrasepsi efektif. Metode kontrasepsi efektif didefinisikan sebagai metode kontrasepsi dengan angka pencegahan kehamilan terbesar. Guna memberikan informasi tambahan mengenai penggunaan kontrasepsi di dunia, dilakukan review mengenai tren pemilihan metode kontrasepsi di beberapa negara di dunia beserta faktor umum ekonomi yang memengaruhi pemilihan metode kontrasepsi.

\section{Metode}

Tinjauan literatur dilakukan dalam laman situs Pubmed dan ScienceDirect dengan kata kunci "effectiveness of contraception"; "Trend of Contraception" dan "Cost Effectivenesss Analysis of Contraception". Pemilihan jurnal berdasarkan kriteria inklusi dan eksklusi. Kriteria inklusi adalah full text jurnal berbahasa inggris yang dipublikasi dalam lima tahun terakhir dengan subjek penelitian wanita usia subur (19-49 tahun) baik menikah atau belum menikah. Sementara kriteria eksklusi adalah jurnal berupa review dan jurnal yang membahas tren penggunaan kontrasepsi pada keadaan khusus, pasien dengan penyakit kejang, diabetes, kanker, HIV, gangguan jantung, dan hati. Tahap tinjauan literatur dapat dilihat pada Gambar 1.

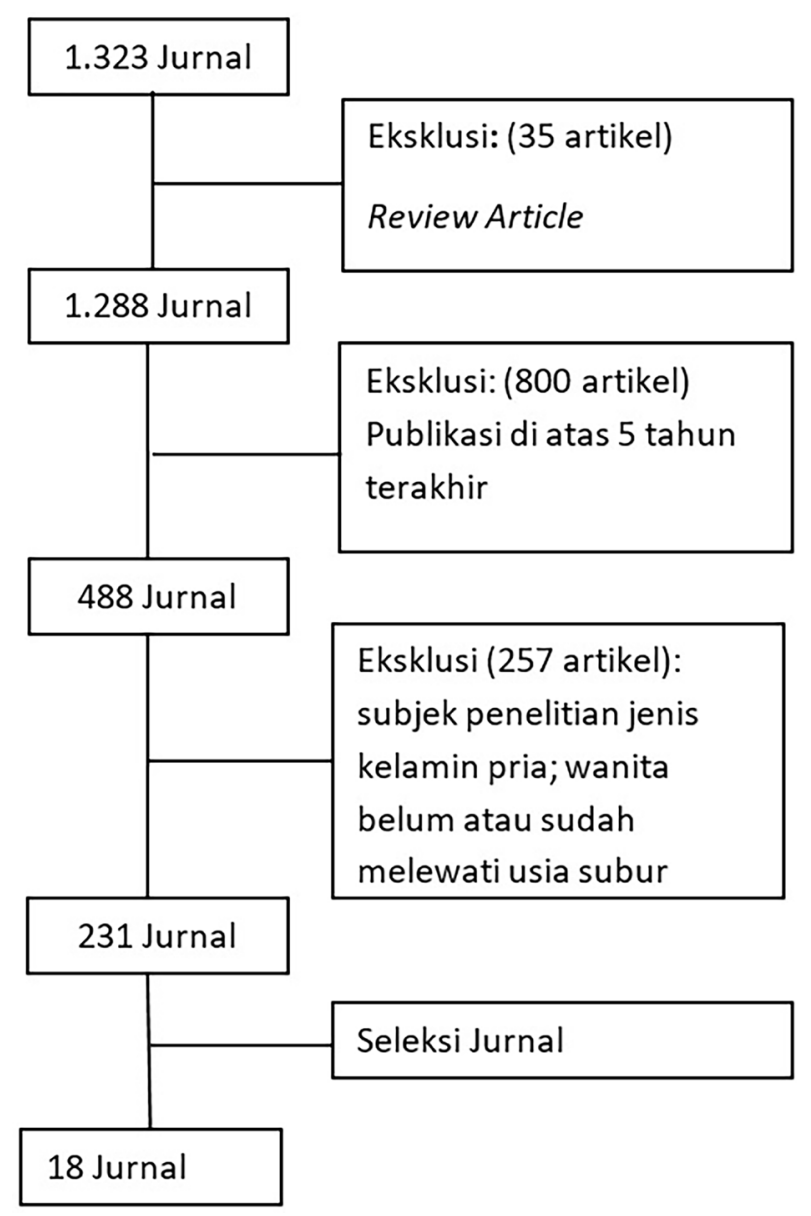

\section{Gambar 1. Tahap Tinjauan Literatur}

Secara umum, pemilihan jurnal dilakukan dalam 4 tahap. Tiap tahap mereduksi jurnal berdasarkan kriteria eksklusi masing-masing. Dilakukan seleksi tahap pertama terhadap 1.323 jurnal berbahasa Inggris dengan jenis jurnal yang diambil di antaranya artikel penelitian. Tahap ini menyisakan 1.288 jurnal. Tahap kedua, digunakan jurnal publikasi 5 tahun terakhir. Tersisa 488 jurnal. Kemudian, direduksi jurnal penelitian yang menggunakan subjek penelitian wanita usia produktif (19-49 tahun). Tahap ketiga menghasilkan 231 jurnal. Kemudian dilakukan seleksi jurnal. Seleksi jurnal dilakukan dengan 
mengulas keseluruhan isi jurnal. Ulasan isi jurnal dilakukan dengan metode PICO (Patient, Intervention, Comparison dan Outcome). Patient merupakan wanita usia subur (19-49 tahun) baik menikah atau belum menikah yang tidak memiliki penyakit kejang, diabetes, kanker, HIV, gangguan jantung, dan hati. Intervention adalah metode kontrasepsi. Comparison adalah peminatan pribadi pasien terhadap metode kontrasepsi. Outcome dalam penelitian ini adalah tren penggunaan metode kontrasepsi. Hanya 18 jurnal yang berhasil melewati seluruh rangkaian screening.

Dari 18 jurnal yang didapat hanya 14 negara yang digambarkan dalam ulasan artikel ini. Hal tersebut dikarenakan terdapat lebih dari satu jurnal yang menggambarkan satu negara. Misalnya Ethiopia dan Amerika Serikat. Dilakukan pengelompokan terhadap 14 negara terpilih berdasarkan kategori kelas ekonomi negara tempat penelitian. Terdapat 4 kategori kelas ekomoni yaitu negara ekonomi berpenghasilan rendah, negara ekonomi berpenghasilan menengah ke bawah, negara ekonomi berpenghasilan menengah ke atas, dan negara ekonomi berpenghasilan tinggi. Pengategorian berdasarkan GNI atau pendapatan nasional bruto (PNB). Kategori negara ekonomi berpenghasilan rendah didefinisikan sebagai negara dengan GNI tidak lebih besar $\$ 1.025$. Kategori negara ekonomi berpenghasilan menengah ke bawah memiliki GNI per kapita antara \$1.026-\$4.035. Kategori negara ekonomi berpendapatan menengah atas memiliki GNI per kapita antara \$4.036-\$12.475 dan kategori negara ekonomi berpenghasilan tinggi memiliki GNI per kapita sebesar $\$ 12.476$ atau lebih. ${ }^{21}$ Kemudian dilakukan ulasan mengenai tren penggunaan kontrasepsi pada tiap negara. Tren penggunaan kontrasepsi didapat dari kecenderungan subjek penelitian dalam pemilihan metode kontrasepsi, melalui ulasan ini diketahui metode kontrasepsi paling banyak digunakan dan metode kontrasepsi yang paling efektif di tiap negara. Metode kontrasepsi paling banyak digunakan merupakan metode kontrasepsi paling banyak dipilih dari populasi penelitian, sedangkan metode kontrasepsi paling efektif merupakan metode kontrasepsi paling banyak mencegah kehamilan. Kemudian dilakukan kajian lebih lanjut mengenai faktor umum yang memengaruhi pemilihan metode kontrasepsi.

\section{Hasil}

Hasil dari tinjauan literatur didapatkan tren pengguna metode kontrasepsi yang paling banyak digunakan dan paling efektif. Kontrasepsi paling banyak digunakan adalah kontrasepsi yang paling banyak dipilih dalam satu populasi penelitian sedangkan kontrasepsi paling efektif merupakan kontrasepsi dengan tingkat keberhasilan pencegahan kehamilan terbesar. Hasil review tren penggunaan kontrasepsi di berbagai negara terdapat pada Tabel 1.

\section{Pembahasan}

Review jurnal ini menggambarkan mengenai metode kontrasepsi paling banyak digunakan dan paling efektif di beberapa negara di dunia beserta faktor umum yang memengaruhi pemilihan metode kontrasepsi.

\section{Gambaran tren penggunaan metode kontrasepsi di beberapa negara di dunia}

Tren penggunaan metode kontrasepsi digambarkan dengan penggunaan metode kontrasepsi paling banyak digunakan. Hasil kajian review, hampir tidak ada perbedaan di negara penghasilan tinggi, menengah, dan berpenghasilan rendah. Tujuh dari empat belas negara yang di-review menjadikan SARC sebagai metode kontrasepsi paling banyak digunakan. SARC seperti pil, injeksi, dan kondom menjadi kontrasepsi yang paling sering digunakan. Metode SARC menjadi metode kontrasepsi mendominasi semenjak tahun 2015, di mana 25 dari 45 negara memilih SARC menjadi metode kontrasepsi paling sering digunakan. SARC lebih banyak digunakan meskipun efektivitasnya tidak lebih baik dibandingkan metode kontrasepsi modern lainnya. ${ }^{26,44,45}$ SARC memiliki keunggulan diantaranya penggunaan yang praktis, murah sehingga dapat dijangkau oleh semua lapisan masyarakat ${ }^{26,46}$.

Di negara kelas ekonomi berpenghasilan rendah seperti Uganda, Ethiopia, dan Senegal keterbatasan akses LARC menjadi salah satu alasan minimnya penggunaan LARC. Penelitian Tabaijuka dkk. tahun 2017 di Uganda, 112 dari 180 responden meyakini metode LARC lebih efektif dibandingkan SARC. Hal tersebut dikarenakan kemampuan pencegahan kehamilan dari SARC sangat 


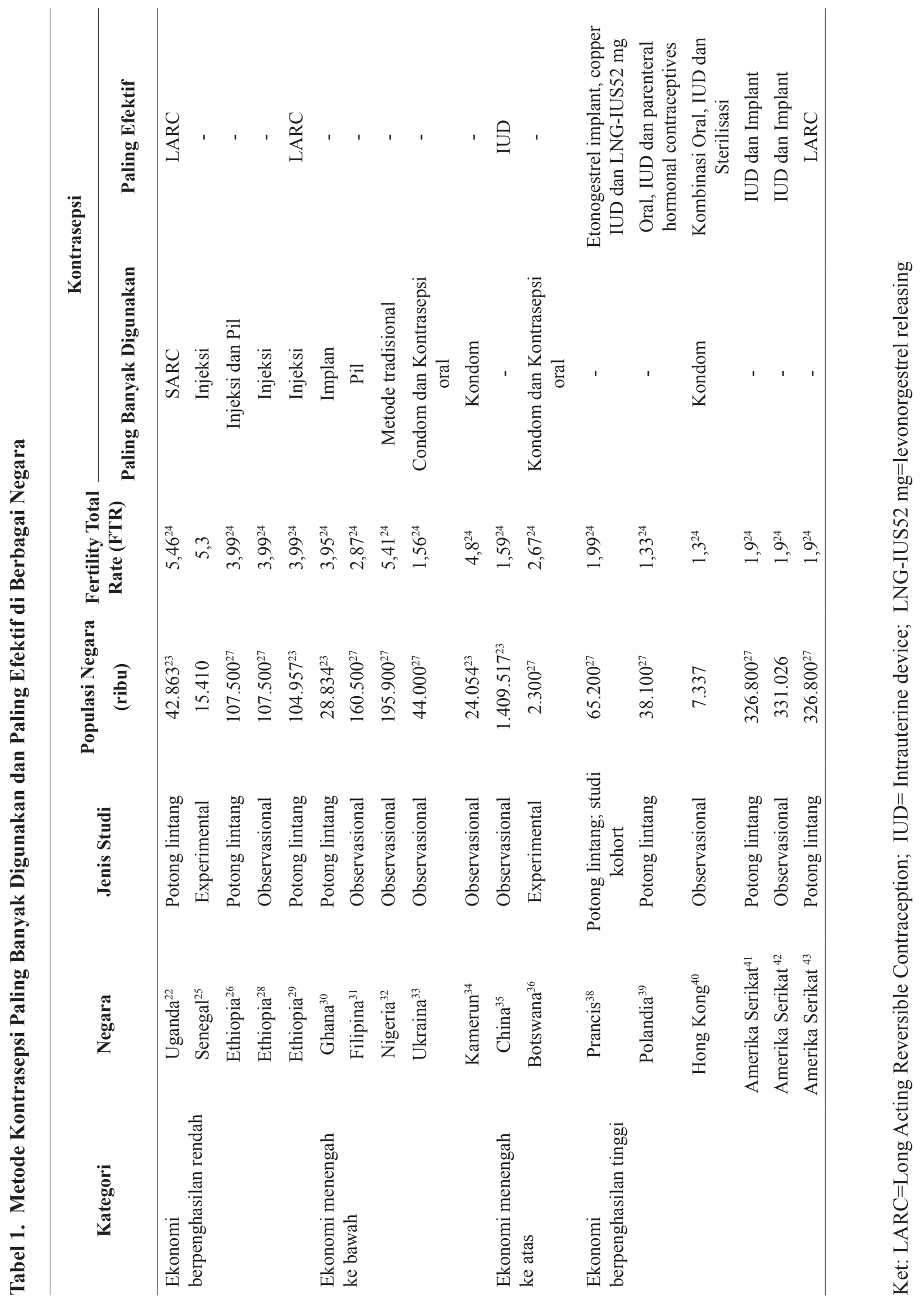


bergantung terhadap level edukasi dan karakteristik pasien. Meskipun begitu, SARC menjadi metode kontrasepsi paling banyak digunakan baik di masyarakat kota maupun desa. Kontrasepsi suntik menjadi SARC yang paling banyak dipilih baik di perkotaan $(31,7 \%)$ dan di perdesaan $(25 \%)$. Ingin hamil dalam jangka waktu dekat dan tidak dapat dukungan dari pasangan untuk menggunakan LARC menjadi alasan masyarakat kota untuk memilih SARC sedangkan alasan masyarakat desa untuk memilih SARC dikarenakan kurangnya kesadaran dan pengetahuan mengenai LARC. Meskipun secara teori masyarakat perkotaan memiliki akses lebih mudah dibandingkan perdesaan. Namun, diketahui bahwa penggunaan LARC di perdesaan $(31,7 \%)$ jauh lebih besar dibanding penggunaan LARC di masyarakat kota (19,2\%). ${ }^{22}$ Senegal menjadi negara kelas ekonomi berpenghasilan rendah lainnya yang memiliki keterbatasan akses kontrasepsi. Satu pertiga wanita subur tidak dapat akses penggunaan kontrasepsi, kemungkinan terbesar hal tersebut disebabkan karena fasilitas kesehatan kehabisan persediaan kontrasepsi, namun belum diketahui pasti penyebab kekosongan persediaan kontrasepsi di Senegal. Penggunaan kontrasepsi di perkotaan lebih besar dibandingkan perdesaan. Hal ini dapat dilihat dari modern contraceptive prevalence rate (MCPR). MCPR didefinisikan sebagai proporsi wanita usia reproduksi (atau pasangannya) yang menggunakan metode kontrasepsi pada titik waktu tertentu. MCPR perkotaan sebesar 37\% sedangkan MCPR perdesaan sebesar 9\%. Suntik menjadi metode kontrasepsi modern yang paling popular diikuti pil dan implan. Terhitung sebanyak 39\% wanita subur di Senegal menggunakan kontrasepsi suntik.

Tiga dari lima negara ekonomi menengah bawah menjadikan SARC sebagai metode kontrasepsi paling banyak dipilih. Bahkan terdapat negara yang masih mempertahankan penggunaan metode kontrasepsi tradisional. Meskipun saat ini sangat jarang ditemukan penggunaan metode kontrasepsi tradisional. Pemilihan kontrasepsi tradisional dikarenakan kekhawatiran terhadap efek samping yang ditimbulkan oleh kontrasepsi modern. Contoh negara yang banyak menggunakan kontrasepsi tradisonal adalah Filipina dan Nigeria, Penelitian dari Marquez dkk. pada tahun 2013 menyatakan di Filipina pengguna kontrasepsi tradisional masih terbilang tinggi meskipun tidak menjadi metode yang mendominasi. Tiga puluh dua persen (32\%) dari 4.560 responden wanita menikah di Filipina masih menggunakan kontrasepsi tradisional dengan teknik senggama terputus menjadi metode kontrasepsi tradisional yang paling banyak digunakan (22\%). Metode senggama terputus merupakan metode kontrasepsi tertua yang dilakukan dengan cara mengeluarkan penis dari vagina sesaat sebelum ejakulasi. Di sisi lain, kontrasepsi oral (36,5\%) dan tubektomi (14\%) menjadi kontrasepsi modern paling banyak digunakan di Filipina. Berbeda dengan negara lain, tubektomi di negara ini menjadi salah satu metode kontrasepsi yang cukup dipandang. Nigeria menjadi negara lainnya yang mempertahankan penggunaan metode kontrasepsi tradisional. Prevalensi penggunaan kontrasepsi di Nigeria lebih kecil dibandingkan dengan negara berpenghasilan menengah kebawah lainnya, hanya sekitar 14,5\%. Penggunaan kontrasepsi terbesar berasal dari daerah barat daya Nigeria (38\%). Semenjak 2008, Nigeria berusaha memperluas akses pengunaan kontrasepsi dan edukasi kepada wanita di negara tersebut. Empat puluh empat koma tiga persen $(44,3 \%)$ responden mengaku bahwa kontrasepsi tradisional menjadi metode kontrasepsi yang digunakan, metode kontrasepsi tradisional paling banyak digunakan adalah pantang periodik $(31,1 \%)$ sedangkan metode kontrasepsi modern paling banyak digunakan adalah pil (18,8\%). Metode pantang periodik dilakukan dengan cara mencatat periode menstruasi dan memprediksi masa subur wanita, dihindari hubungan seksual pada saat masa subur wanita. ${ }^{31,32,35}$ Selain karena keterbatasan akses kontrasepsi, peraturan pemerintah setempat mengenai kontrasepsi sangat memengaruhi pola penggunaan kontrasepsi itu sendiri. Negara Ukraina memiliki peraturan pelarangan promosi LARC di media sosial. Hal tersebut menyebabkan minimnya pengetahuan masyarakat mengenai LARC, oleh karenanya pemilihan metode kontrasepsi di negara ini sangat bergantung kepada fasilitas kesehatan dan pendapatan per kapita wilayah. Hingga tahun 2018 LARC yang available from Ukrina hanya metode IUD dengan biaya pemasangan 15-20 EUR. Survei yang dilakukan Podolsky dkk. menyatakan bahwa $75 \%$ dan $46 \%$ dari 500 responden memilih kondom dan kontrasepsi pil sebagai metode kontrasepsi yang digunakan. ${ }^{25,33}$ 
Berbeda dengan Ukraina, kebijakan dan pengetahuan pemerintah kategori ekonomi menegah atas dan berpenghasilan tinggi cenderungmendukung penggunaan LARC. Contoh negara ekonomi kelas menengah adalah Cina. Kebijakan pemerintah Cina justru mendukung penggunaan LARC di negaranya. Cina telah menerapkan kerangka kebijakan yang ketat mengenai kontrasepsi guna mengendalikan angka penduduk sejak 1979. Kebijakan saat ini di antaranya wajib dilakukan pemasangan IUD untuk wanita dengan satu anak, aborsi untuk kehamilan tidak melalui perkawinan sah dan sterilisasi untuk pasangan dengan dua anak atau lebih. ${ }^{46}$ Prevalensi kontrasepsi Cina berada di tingkat tertinggi di dunia pada $89,20 \%$ di antara wanita yang menikah di Cina 2010. Penggunaan kontrasepsi jangka panjang sangat tinggi, di antara wanita menikah usia reproduktif pada 2010 penggunaan perangkat kontrasepsi adalah 48,15\% dan sterilisasi wanita $31,7 \%$. Sebaliknya, penggunaan kontrasepsi oral dan kondom relatif rendah (masing-masing 0,98\% dan 9,32\% pada 2010). Faktor kunci yang memengaruhi hal tersebut di antaranya adalah kewajiban, kesadaran, dan informasi yang relatif rendah tentang SARC. Sama halnya dengan Cina, Hong Kong menjadi negara berpenghasilan tinggi. Pemerintah Hong Kong mendorong lebih banyak wanita untuk menggunakan kontrasepsi yang lebih efektif seperti pil kontrasepsi hormonal kombinasi, IUD, atau sterilisasi. Hal ini berlandaskan metode pil kontrasepsi hormonal kombinasi, IUD, dan sterilisasi bila digunakan dengan tepat memberikan tingkat keberhasilan $>99 \%$ pada tahun pertama penggunaan. Tingkat keberhasilan $>99 \%$ menandakan hanya ada satu kehamilan tak diinginkan per 100 pasangan pengguna kontrasepsi tersebut. . $^{35,46,47}$

\section{Kontrasepsi yang Paling Efektif}

Berbeda dengan kontrasepsi yang sering digunakan, kontrasepsi paling efektif merupakan metode kontrasepsi yang mampu menunda kehamilan paling besar. ${ }^{48}$ Mayoritas negara baik negara berpenghasilan rendah, menengah bawah, menengah atas, dan berpenghasilan tinggi meyakini LARC merupakan metode kontrasepsi paling efektif dalam pencegahan kehamilan. ${ }^{22,29,35,37-41}$ Hal tersebut didukung data WHO yang menyatakan metode kontrasepsi paling efektif merupakan metode
LARC dan sterilisasi. ${ }^{43,49}$ Tingkat efektif dari suatu kontrasepsi digambarkan melalui persentase efektivitas. WHO pada tahun 2017 menyatakan bahwa efektivitas kontrasepsi metode vasektomi sebesar 99,85\% dan tubektomi sebesar 99,5\%. Sama halnya dengan metode sterilisasi, efektivitas dari metode LARC mencapai lebih dari 99\%; baik itu implan (99,95\%); IUD (99,2\%); dan IUD LNG (99,8\%). Angka tersebut jauh lebih besar dibandingkan dengan metode SARC seperti injeksi (97\%); injeksi kombinasi (98\%); pil (92\%); pil kombinasi (92\%); dan kondom (85\%). Persentase efektivitas didefinisakan sebagai pencegahan kehamilan per 100 PUS pengguna metode kontrasepsi tersebut. Apabila suatu metode memiliki efektivitas 97\%, terjadi 97 pencegahan kehamilan per 100 PUS pengguna metode tersebut. ${ }^{50}$

Meskipun menjadi metode kontrasepsi paling efektif, namun tingkat penggunaannya memang masih rendah di beberapa negara. Negara dengan perekonomian dan pendidikan tinggi merupakan modal utama dalam penyedian LARC. Di negara dengan penghasilan tinggi tersedia lebih banyak akses penelitian komprehensif mengenai metode kontrasepsi paling efektif. Bahkan beberapa penelitian menyatakan bahwa LARC bukan hanya metode kontrasepsi dengan tingkat efektivitas paling tinggi tetapi juga menjadi metode kontrasepsi paling cost effective. Agostini dkk. pada tahun 2018 di Prancis menyatakan bahwa biaya kontrasepsi tahunan rata-rata untuk tahun pertama penggunaan berkisar antara $€ 145$ untuk kontrasepsi oral kombinasi; $€ 308$ untuk LevonorgestrelIntra Uterine System (LNG-IUS) $52 \mathrm{mg}$; dan €88 untuk penggunaan metode implan etonogestrel. Jika memperhatikan biaya maka metode implan etonogestrel menjadi metode kontrasepsi cost effective namun ketika biaya kehamilan yang tidak direncanakan diperhitungkan, biaya kontrasepsi tahunan rata-rata untuk tahun pertama penggunaan lebih rendah untuk kontrasepsi oral $(€ 251)$ dan IUD tembaga ( $€ 257)$ dibandingkan dengan implan etonogestrel $(€ 300)$ dan LNG -IUS $52 \mathrm{mg}(€ 323)$. Penelitian yang dilakukan oleh Barndon di Amerika Serikat (AS) membandingkan biaya penggunaan LARC (IUD), oral kontrasepsi levonorgestrel dan kombinasi keduanya. Dari 1000 responden wanita, dilaporkan bahwa penggunaan IUD memperkirakan 
biaya medis langsung $\$ 1,376,000$ dan 61 kehamilan yang tidak diinginkan. Biaya medis langsung oral kontrasepsi lenovorgestrel $\$ 1.279 .000$ dengan 150 kehamilan yang tidak diinginkan. Sementara biaya medis langsung untuk kombinasi sebesar $\$ 1.558 .000$ dan 63 kehamilan yang tidak diinginkan. Kemudian, dilakukan analisis incremental dan didapatkan hasil bahwa IUD 63\% lebih cost-effective dibandingkan metode kontrasepsi lainnya. ${ }^{48,51}$

\section{Faktor-faktor yang Memengaruhi Pemilihan Metode Kontrasepsi}

Dalam review ini diperoleh bahwa metode kontrasepsiyang diyakinipaling efektif oleh sebagian besar negara adalah metode LARC. ${ }^{22,29,35,37-41}$ LARC menjadi efektif karena pencegahan kehamilan yang tidak tergantung pada kepatuhan pasien menggunakan kontrasepsi. Terlebih saat ini, jam kerja rata-rata pekerja berkisar 12 hingga $16 \mathrm{jam}$. Hal tersebut menjadi salah satu potensi ketidakpatuhan pasien terhadap penggunaan kontrasepsi jangka pendek, oleh karenanya penggunaan kontrasepsi jangka pendek lebih besar potensi gagal terhadap pencegahan kehamilan. Meskipun sudah banyak penelitian yang mendeklarasikan efektivitas dari LARC, namun tidak semua pengguna kontrasepsi memilih alternatif metode LARC. Perbedaan sosial dan budaya dalam suatu negara sangat memengaruhi pemilihan metode kontrasepsi. Faktor sosial yang memengaruhi dalam pemilihan kontrasepsi di antaranya tingkat pendidikan baik suami maupun istri; pengetahuan mengenai metode kontrasepsi LARC; agama dan status pekerjaan. Ronald dkk. melakukan penelitian mengenai faktor sosial yang memengaruhi dalam pemilihan kontrasepsi pada tahun 2014 menyertakan 565 subjek di Uganda. Dalam penelitian ini faktor sosial ekonomi yang dijadikan variabel independen di antaranya tingkat pendidikan, tempat tinggal, agama, status perkawinan, status pekerjaan, status sosial ekonomi yang dinilai dengan menggunakan indeks kekayaan, dan wilayah geografis tempat tinggal. Analisis dibuat menggunakan regresi logistik berganda berdasarkan desain survei yang kompleks menyatakan bahwa faktor sosial yang signifikan secara statistik ( $\mathrm{p}$ value $<0,05$ ) memengaruhi pemilihan kontrasepsi adalah pengetahuan mengenai metode kontrasepsi LARC baik pengetahuan mengenai efektivitas maupun administratif dari metode LARC, metode LARC yang diikuti sertakan adalah IUD dan implan dengan nilai $p$ sebesar 0,006 dan $0,0009 .^{29,52}$

$$
\text { Penelitian lain dilakukan oleh Martin }
$$

Palamuleni dkk. di Malawi tahun 2013, menggunakan analisis multivariate dengan 3.261 sampel peserta menyatakan bahwa umur, agama, kekayaan, dan pendidikan menjadi faktor signifikan yang memengaruhi dalam pemilihan metode kontrasepsi. Hasil penelitian Martin didukung oleh penelitian Hossain dan kawan kawan yang dilakukan di Bangladesh pada tahun 2014. Data kontrasepsi diambil dari Bangladesh Demographic and Health Survey (BDHS) 2014 yang dikumpulkan dengan menggunakan teknik stratified random sampling. Hasil analisis regresi logistik berganda menyatakan bahwa faktor umum yang signifikan memengaruhi penggunaan kontrasepsi adalah tempat tinggal, agama, usia, aktivitas seksual, jumlah anak, dan tingkat pendidikan. Pendidikan menjadi salah satu faktor yang penting, tingginya pendidikan seseorang dapat memengaruhi faktor penyerapan informasi mengenai kontrasepsi dan kesadaran akan jumlah keluarga ideal. ${ }^{4,53-55}$

Dari tabel hasil review, terlihat bahwa faktor ekonomi dan aspek demografi tidak berpengaruh terhadap pemilihan metode kontrasepsi. Dari sisi fertility total rate (FTR), terdapat perbedaan karakteristik demografi di negara ekonomi berpenghasilan rendah, menengah bawah, menengah atas, dan berpenghasilan tinggi. Semakin tinggi kelas ekonomi negara, semakin kecil FTR negara tersebut. Namun, perbedaan pendapatan perorang di suatu negara (kelas ekonomi) dan perbedaan karakteristik demografi tidak memengaruhi pemilihan metode kontrasepsi. Hal tersebut dikarenakan tidak ada perbedaan tren penggunaan metode kontrasepsi baik di kelompok negara ekonomi rendah, menengah bawah, menengah atas, dan negara ekonomi tinggi.

\section{Limitasi}

Limitasi dalam penelitian ini tidak dijelaskan mengenai hubungan pemilihan kontrasepsi dengan utilitas pasien. Representatif jurnal yang digunakan untuk suatu negara sangat bergantung pada jumlah sampel dalam masing-masing penelitian dan kualitas dari jurnal tersebut, tidak ada penyaringan mengenai riwayat kehamilan responden. 


\section{Kesimpulan}

Dalam ulasan jurnal kali ini didapati hampir tidak ada perbedaan tren penggunaan metode kontrasepsi di negara ekonomi penghasilan rendah, menengah bawah, menengah atas, dan negara penghasilan tinggi. Short acting reversible contraceptive (SARC) menjadi metode kontrasepsi paling banyak digunakan sedangkan Long acting reversible contraceptive (LARC) merupakan metode kontrasepsi paling efektif dengan persentase efektivitas paling tinggi, bahkan beberapa penelitian menyatakan bahwa LARC merupakan kontrasepsi paling cost-effective. Faktor umum yang memengaruhi pemilihan metode kontrasepsi diantaranya tempat tinggal, agama, dan tingkat pendidikan.

\section{Saran}

Mendorong penggunaan LARC guna mengefektifkan usaha pengaturan jumlah penduduk di Indonesia. Hal ini dapat diimplementasikan dengan bantuan kebijakan pemerintah. Salah satu program yang dapat mendukung realisasi penggunaan LARC adalah BPJS Kesehatan. KB merupakan salah satu program kesehatan yang di cover oleh pemerintah.

\section{Kontribusi Penulis}

DKRD dan RKS bekerja sama menyusun garis besar rancangan review artikel. DKRD menyiapkan referensi dan menuliskan draf artikel. RKS memberikan masukan terkait teknis revisi artikel.

\section{Ucapan Terima Kasih}

Ucapan terima kasih ditujukan kepada Universitas Padjadjaran, pembimbing penelitian, sumber rujukan, dan orang-orang yang sudah membantu dalam penelitian.

\section{Daftar Rujukan}

1. Population Reference Bureau. 2019 World Population Data Sheet. [Internet]. 2019. [diakses pada 11 Januari 2020] Tersedia pada: https:// www.prb.org/worldpopdata/.

2. United National. World Population Prospects 2019: Highlight. [Internet]. 2019. [diakses pada 11 Januari 2020]. Tersedia pada: https:// population.un.org/wpp/Publications/Files/
WPP2019_Highlights.pdf.

3. Sitruk-Ware R, Nath A, Mishell Jr DR. Contraception technology: past, present and future. Contraception. 2013;87(3):319-30. doi: 10.1016/j.contraception.2012.08.002

4. Peterson EWF. The role of population in economic growth. SAGE Open. 2017;7(4). doi: 10.1177/2158244017736094

5. Van Bavel J. The world population explosion: causes, backgrounds and projections for the future. Facts Views Vis Obgyn. 2013;5(4):28191.

6. Mittal R, Mittal CG. "Impact of population explosion on environment." WeSchool "Knowledge Builder"-The Natl J. 2013;1(1): 1-5.

7. Manisalidis I, Stavropoulou E, Stavropoulous A, Bezirtzoglou E. Environmental and health impacts of air pollution: a review. Front Public Health. 2020;8:14. doi:10.3389/ fpubh.2020.00014

8. Nugroho T, Utama BI. Masalah Kesehatan Reproduksi Wanita. Yogyakarta: Nuha Medika; 2014.

9. Jain R, Muralidhar S. Contraceptive methods: needs, options and utilization. JObstet Gynaecol India. 2011;61(6):626-34. doi: 10.1007/s13224011-0107-7

10. United Nations Children's Fund (UNICEF). Maternal Mortality. [Internet]. 2019. [diakses pada 11 Januari 2020] Tersedia pada: https:// data.unicef.org/topic/maternal-health/maternalmortality/

11. Kementerian Kesehatan. Pentingnya Penggunaan Alat Kontrasepsi. [Internet]. 2018. [diakses pada 15 Januari 2020]. Tersedia pada: http://promkes.kemkes.go.id/pentingnyapenggunaan-alat-kontrasepsi.

12. Almalik M, Mosleh S, Almasarweh I. Are users of modern and traditional contraceptive methods in Jordan different? East Mediterr Health J. 2018;24(4):377-84. doi:10.26719/2018.24.4.377

13. Hubacher D, Trussell J. A definition of modern contraceptive methods. Contraception. 2015; 92(5):420-1.doi:10.1016/j.contraception. 2015.08.008

14. Shattuck D, Perry B, Packer C, Quee C. A 
Review of 10 Years of Vasectomy Programming and Research in Low-Resource Settings. 2020;647-60. doi:10.9745/GHSP-D-16-00235

15. Puwar BT, Patel VD, Vyas S. ORIGINAL ARTICLE A Study on Factors Affecting Vasectomy in Ahmedabad City of Gujarat. Natl J Community Med. 2017;8(4):208-12.

16. Creanga AA, Gillespie D, Tsui AO. Low Use of Contraception Among Poor Women in Africa : An Equity Issue. Bull World Health Organ .2011:258-66. doi:10.2471/BLT.10.083329

17. Mahadevappa K, Prasanna N, Channabasappa RA. Trends of Various Techniques of Tubectomy: A Five Year Study in a Tertiary Institute. J Clin Diagn Res. 2016;10(1):QC04QC7. doi:10.7860/JCDR/2016/16863.7104

18. National Health Service (NHS). Vasectomy (male sterilisation). [Internet]. 2018. [diakses pada 12 Januari 2020] Tersedia pada:https:// www.nhs.uk/conditions/contraception/ vasectomy-male-sterilisation/

19. Women MAUS. HHS Public Access. 2016;126(5):917-27.

20. Hopkins K, Hubert C, Coleman-minahan K, Jean A, White K, Grossman D, et al. Unmet Demand for Short-Acting Hormonal and Long-Acting Reversible Contraception Among Community College Students In Texas. Journal of American College Health. 2018;8481:360-8. doi:10.1080/ 07448481.2018.1431901

21. World Bank. New Country Classifications by income level: 2016-2017. [Internet]. 2016. [diakses pada 27 Desember 2019] Tersedia pada: https://blogs.worldbank.org/opendata/ new-country-classifications-2016

22. Tibaijuka L, Odongo R, Welikhe E, Mukisa W, Kugonza L, Busingye I, et al. Factors Influencing Use of Long-Acting Versus Short-Acting Contraceptive Methods Among ReproductiveAge Women In A Resource-Limited Setting. BMC Womens Health. 2017;17(1):1-13. doi: 10.1186/s12905-017-0382-2

23. United Nations. World Population Prospects 2017 - Data Booklet. [Internet]. 2017 [diakses pada 12 Januari 2020] Tersedia pada: https:// www.un.org/development/desa/pd/content/ world-population-prospects-2017-revisiondata-booklet
24. United Nations. World Population Prospects 2015 - Data Booklet. [Internet]. 2015. [diakses pada 12 Januari 2020]. Tersedia pada: http:// www.un.org/esa/population/publications/ WPP2004/2004Highlights_finalrevised.pdf

25. Cavallaro FL, Duclos D, Baggaley RF, PennKekana L, Goodman C, Vahanian A, et al. Taking Stock: Protocol for Evaluating a Family Planning Supply Chain Intervention in Senegal. Reprod Health. 2016;13(1):1-14. doi:10.1186/ s12978-016-0163-7

26. Abraha TH, Belay HS, Welay GM. Intentions on Contraception Use and Its Associated Factors Among Postpartum Women in Aksum Town, Tigray Region, Northern Ethiopia: A Community-Based Cross- Sectional Study. Reprod Health. 2018;15(1):188. doi: 10.1186/ s12978-018-0632-2

27. United Nations Population Fund (UNFPA). The Power of Choice: Reproductive Rights and the Demographic Transition. State World Popul 2018 [Internet]. 2018. [diakses pada 12 Januari 2020] Tersedia pada: https://www. unfpa.org/sites/default/files/pub-pdf/UNFPA_ PUB_2018_EN_SWP.pdf

28. Wado YD, Gurmu E, Tilahun T, Bangha M. Contextual influences on the choice of longacting reversible and permanent contraception in Ethiopia: A multilevel analysis. PloS one. 2019; 14(1). doi: 10.1371/journal.pone.0209602

29. Shiferaw K, Musa A. Assessment of utilization of long acting reversible contraceptive and associated factors among women of reproductive age in Harar City, Ethiopia. Pan Afr Med J. 2017;28:1-8. doi:10.11604/ pamj.2017.28.222.13475

30. Rominski SD, SKMorhe E, Maya E, Manu A, Dalton VK. Comparing Women's Contraceptive Preferences With Their Choices in 5 Urban Family Planning Clinics in Ghana. Glob Health Sci Pract. 2017;5(1):65-74. doi:10.9745/ GHSP-D-16-00281

31. Marquez MP, Kabamalan MM, Laguna E. Traditional and Modern Contraceptive Method Use in the Philippines: Trends and Determinants 2003-2013. Wiley Online Library. 2013;1-19. doi: 10.1111/sifp.12051

32. Ajayi AI, Adeniyi OV, Akpan W. Use of 
traditional and modern contraceptives among childbearing women: findings from a mixed methods study in two southwestern Nigerian states. BMC Public Health. 2018;18:1-9. doi:10.1186/s12889-018-5522-6

33. Podolskyi V, Gemzell-danielsson K, Marions L. Contraceptive experience and perception, a survey among Ukrainian women. BMC Public Health. 2018;4-9. doi:10.1186/s12905-0180651-8

34. Ajong AB, Njotang PN, Kenfack B, Yakum $\mathrm{MN}, \mathrm{Mbu}$ ER. Knowledge of women in family planning and future desire to use contraception: a cross sectional survey in Urban Cameroon. Bmc Research Notes. 2016; 9(1): 347. doi:10.1186/ s13104-016-2155-7

35. Che Y, Dusabe-richards E, Wu S, Jiang Y, Dong X, Li J, et al. A qualitative exploration of perceptions and experiences of contraceptive use, abortion and post-abortion family planning services (PAFP) in three provinces in China. BMC Women's Health. 2017;1-13. doi:10.1186/ s12905-017-0458-z

36. Mokgetse M, Mokholelana M, Africa S. Female condom acceptability and use amongst young women in Botswana. Curationis. 2015;(2014):16. doi:10.4102/curationis.v41i1.1887

37. Agostini A, Godard C, Laurendeau C, Benmahmoud A, Lafuma A, Doz M, et al. Effectiveness and cost of contraception in France (FACET study): a cohort study from the French National Healthcare Insurance Database. Eur $J$ Obstet Gynecol Reprod Biol. 2018;229:137-43. doi:10.1016/j.ejogrb.2018.08.007

38. Warzecha D, Szymusik I, Pietrzak B, Kosinskakaczynska K, Sierdzinski J, Sochacki-wojcicka $\mathrm{N}$, et al. Sex education in Poland - a crosssectional study evaluating over twenty thousand polish women's knowledge of reproductive health issues and contraceptive method. $B M C$ public health. 2019;1-8. doi:10.1186/s12889019-7046-0

39. Lo SST, Fan SYS. Acceptability of the combined oral contraceptive pill among Hong Kong women. Hong Kong medical journal = Xianggang yi xue za zhi. 2016;22(3):231-6. doi: 10.12809/hkmj154672

40. Caldwell MT, Choi H, Levy P, Dalton VK,
Misra DP. Effective Contraception Use by Usual Source of Care: An Opportunity for Prevention. Women's Health Issues. 2018;306312. doi:10.1016/j.whi.2018.03.001

41. Cabral MA, Schroeder R, Armstrong EM, et al. Pregnancy Intentions, Contraceptive Knowledge And Educational Aspirations Among Community College Students. Perspect Sex Reprod Health.2015. doi:10.1363/ psrh.12081

42. Kavanaugh, M. L., Jerman, J., \& Finer, L. B. (2015). Changes in Use of Long-Acting Reversible Contraceptive Methods Among U.S. Women, 2009-2012. Obstet Gynecol. 126(5), 917. doi:10.1097/AOG.0000000000001094

43. Philadelphia PAC. LARC versus SARC: Major Study Demonstrates Clear Benefits of LongActing Reversible Contraception Compared to Short-Acting Reversible. Am J Obstet Gynecol. 2016.

44. United Nations. Trends in Contraceptive Use Worldwide. [Internet]. 2015. [diakses pada 26 December 2019] Tersedia pada: https://www.un.org/en/development/ desa/population/publications/pdf/family/ trendsContraceptiveUse2015Report.pdf

45. Lab WD. World Povert Clock. [Internet]. 2019. [diakses pada 14 Januari 2020] Tersedia pada: https://worldpoverty.io/.2019

46. Famplan. Family Planning Knowledge, Attitude and Practice in Hong Kong Survey 2012. [Internet]. 2012. [diakses pada 14 Januari 2020]. Tersedia pada: http://www.famplan.org. $\mathrm{hk} / \mathrm{fpahk} / \mathrm{en} /$ template 1 .asp? style=template 1 . asp\&content=info/research.asp. 2012

47. Trussell J. Contraceptive failure in the United States. Contraception. 2011;83:397-404 doi:10.1016/j.contraception.2011.01.021

48. ManuscriptA.NIH Public Access. 2013;79(1):514.

49. Cremer, M. L., Holland, E., Monterroza, M., Duran, S., Singh, R., Terbell, H., \& Edelman A. Exploring factors in the decision to choose sterilization vs alternatives in rural El Salvador. Medscape J Med. 2008;10(8):183.

50. National Health Service (NHS). How Effective is Contraception at Preventing Pregnancy? [Internet]. 2017. [diakses pada 22 December 
2020] Tersedia pada: https://www.nhs.uk/ conditions/contraception/how-effectivecontraception/

51. Turok DK, Schwarz EB. year. 2019;218(5):118

52. Andi, J. R., Wamala, R., Ocaya, B., \& Kabagenyi, A. (2014). Modern contraceptive use among women in Uganda: An analysis of trend and patterns (1995-2011). Etude Popul Afr. 28(2), 1009. doi:10.11564/28-0-553

53. Borenstein E, Kendal J, Feldman M. Cultural niche construction in a metapopulation. Theor
Popul Biol. 2006;70:92-104. doi:10.1016/j. tpb.2005.10.003

54. Kendal J, Ihara Y FM. Cultural Niche Construction With Application to Fertility Control: A Model for Education and Social Transmission of Contraceptive Use. Morrison Institute for Population and Resource Studies. 2005.

55. Palamuleni ME. Socio-economic and demographic factors affecting contraceptive use in Malawi. African journal of reproductive health,2013;17(3):91-104. 